\title{
Work ability among nursing personnel in public hospitals and health centers in Campinas - Brazil ${ }^{1}$
}

\author{
Inês Monteiro ${ }^{\mathrm{a},}$, Manuela de Santana Pi Chillida ${ }^{\mathrm{b}}$ and Luciana Contrera Moreno ${ }^{\mathrm{b}}$ \\ ${ }^{a}$ Faculty of Medical Sciences. University of Campinas - UNICAMP. \\ ${ }^{\mathrm{b}}$ Hospital das Clínicas. University of Campinas - UNICAMP. Campinas, Brazil. \\ ${ }^{\mathrm{c}}$ Federal University of Mato Grosso do Sul. Brazil.
}

\begin{abstract}
Nursing personnel is essential in hospital, health centers and enterprises and is the large work force in health system. A cross-sectional study was conducted in a large city in two public hospitals and five health centre with the objective of to evaluate the work ability and health aspects of nursing staff. The sample was composed by 570 workers. The Work Ability Index - WAI and a questionnaire with socio-demographic, health and life style data was applied. The majority of workers was women (83\%), married (50.4\%), and was working in night shift work (65.6\%); 61.4\% was auxiliary nursing, $22.3 \%$ was registered nurses (RN). The average age was 38.9 years (SD 7.8) and the Body Mass Index mean was 25.8 (SD 5.3). Only 17.2\% referred to practice at least 150 minutes of physical exercise five times per week or more. $26.8 \%$ had a second job. The work ability mean was 39.3 (SD 5.3) points. Age had a negative correlation with WAI ( $\mathrm{p}=0.0052$ ). Public hospital and health centre workers had poor work ability score when compared with workers from another branches. Public policies related to workplace health promotion need to be implemented in public hospital and health centre to improve the work ability.
\end{abstract}

Keywords: life style, work ability, aging, nursing staff

\section{Introduction}

Nursing staff is essential in hospital, health centers and enterprises and is the largest work force in health system in Brazil and the category was composed by auxiliary nursing, technician nursing and registered nurses.

Unfavorable aspects of nursing work was quoted such as shift work, night work, long hours journey, diseases and working conditions [1,3-4].

In Brazil the majority of nursing staff jobs is concentrated in public hospital and health centers from federal, state and municipal services with better income when compared with the private sector.

Work ability it is an important concept developed by Finnish researchers during 1980 and The Work Ability Index, an instrument translated for 26 lan- guages [6], "reveals how well a worker is able to perform his or her work" [7]. It "is primarily a question of a balance between work and personal resources. In practice people search for an optimal balance throughout their entire work life" and it "may be very different in different phases of work life" [6].

The aim of this study was to evaluate the work ability, health aspects and life style among nursing staff.

\section{Method}

Two cross-sectional studies were developed in Campinas city, one from public municipal hospital $(n=163)$ and health centers $(n=105)$ nursing staff, and another in a shift work nursing staff at public state hospital ( $\mathrm{n}=302)$.

\footnotetext{
${ }^{*}$ Corresponding author. Rua Tessalia V. Camargo,126.13083-887, Campinas, Brazil. inesmon@fcm.unicamp.br.Phone: 55-19-35218820.
} 
The sample was composed by 570 workers and The Work Ability Index - WAI [7] and a questionnaire with socio-demographic, health and life style data [8] was applied.

The WAI has seven items: (1) current work ability compared with the life time best, (2) work ability in relation to the demands of the job, (3) number of current diseases diagnosed by a physician, (4) estimated work impairment due to diseases, (5) sick leave during the past year, (6) own prognosis of work ability two years from now, (7) mental resources and vary from 7 to 49 points [t].

Work ability score was the independent variable and socio-demographic, health and life style were the dependent variables. Data was analysed with SAS $9.2^{\circledR}$ software and descriptive and statistical tests was performed.

The research was approved by the Ethical Board of the Faculty of Medical Sciences of the University of Campinas.

\section{Results and discussion}

The majority of workers was women $(83 \%)$, married $(50.4 \%)$, and was working in night shift work $(65.6 \%) ; 61.4 \%$ was auxiliary nursing, $22.3 \%$ was registered nurses $(\mathrm{RN})$ and $16.3 \%$ technician nursing.

Only $5.1 \%$ referred to have a manager position.

The average age was 38.9 years (SD 7.8) ranging between 20 and 60 years, and the age bracket from 40-49 years was the most prevalent $(40.4 \%)$; and the Body Mass Index - BMI mean was 25.8 (SD 5.3).

Only $17.2 \%$ referred to practice at least $150 \mathrm{~min}$ utes of physical exercise five times per week or more. It was found a correlation between physical activity at least 150 minutes per week and disease with the diagnosis of a physician $\left(\mathrm{x}^{2}=0.0007\right)$.

One important aspect is that $26.8 \%$ had a second job, frequently, in the same branch, which is an unfavourable condition, concerned to long work hours, attention demand and strain at work.
In a survey performed in Sao Paulo university hospital authors found that $31.5 \%$ of the health care shift workers had a second job [5].

In relation to life style the majority of the workers did house work activities (89.6\%). Tobacco use was referred by $19.6 \%$ of the workers.

It is a high value for Brazil where the average found in phone interviews in the federal program VIGITEL - for tobacco use was $15.2 \%$ [2]. Alcohol intake was related by $33.4 \%$ of the workers.

The work ability mean was 39.3 (SD 5.3) points. Men were younger than women - mean age 35.6 (SD 6.7) and 39.5 (SD 7.9) respectively; and men had a little higher value in relation to work ability mean 40.4 (SD 5.4) and 39.1 (SD 5.2), respectively.

Age had a negative correlation with WAI $(p=0.0052)$. Public hospital and health centre workers had poor work ability score when compared with workers from another branches [9].

Another important aspect is that $71.2 \%$ of the subjects referred at least one disease diagnosed by a physician. The most frequently diseases were: slight mental disorder or problem (16\%), high blood pressure $(13.7 \%)$, repeated infections of the respiratory tract $(10.5 \%)$, obesity $(9.8 \%)$, chronic sinusitis $(9.7 \%)$, gastritis or duodenal irritation $(8.4 \%)$ and allergic rash or eczema $(8.1 \%)$.

Poor and moderate work ability categories totalized $27.7 \%$ and request actions [7] to restore or improve work ability.

Managers need to pay attention, in Brazil, to this important characteristic, because the poor result of the Work Ability, when was analyzed in The Work and Health Research Group data bank, among more than 5000 workers, the poorest work ability value were among civil servants [10].

Current work ability - the first item of WAI meaning "assume that your work ability at its best has a value of 10 points. How many points would you give your current work ability?" [7], had mean value of 8.2 (SD1.3), which was referred as good result [11].

The Cronbach's alpha was 0.79 . 
Table 1

Distribution of the sample according to socio-demographic, work and health characteristics, life style and work ability category.

\begin{tabular}{|c|c|c|c|c|c|c|}
\hline & & $\mathrm{n} \quad \%$ & Variable & & $\mathrm{n}$ & $\%$ \\
\hline & & $\begin{array}{ll}105 & 18.4 \\
163 & 28.6 \\
302 & 53.0\end{array}$ & Place of work & $\begin{array}{l}\text { Health Center } \\
\text { Municipal hospital } \\
\text { State hospital }\end{array}$ & $\begin{array}{l}105 \\
163 \\
302\end{array}$ & $\begin{array}{l}18.4 \\
28.6 \\
53.0\end{array}$ \\
\hline & & $\begin{array}{rr}97 & 17.0 \\
473 & 83.0\end{array}$ & Gender & $\begin{array}{l}\text { Male } \\
\text { Female }\end{array}$ & $\begin{array}{r}97 \\
473\end{array}$ & $\begin{array}{l}17.0 \\
83.0\end{array}$ \\
\hline & & $\begin{array}{rr}77 & 13.5 \\
219 & 38.5 \\
230 & 40.4 \\
43 & 7.6\end{array}$ & Age bracket (years) & $\begin{array}{l}20-29 \\
30-39 \\
40-49 \\
\geq 50\end{array}$ & $\begin{array}{r}77 \\
219 \\
230 \\
43\end{array}$ & $\begin{array}{r}13.5 \\
38.5 \\
40.4 \\
7.6\end{array}$ \\
\hline & & $\begin{array}{rr}350 & 61.4 \\
93 & 16.3 \\
127 & 22.3\end{array}$ & Work position & $\begin{array}{l}\text { Auxiliary nursing } \\
\text { Technician nursing } \\
\text { Registered Nurse }\end{array}$ & $\begin{array}{r}350 \\
93 \\
127 \\
\end{array}$ & $\begin{array}{l}61.4 \\
16.3 \\
22.3 \\
\end{array}$ \\
\hline & & $\begin{array}{rr}541 & 94.9 \\
29 & 5.1\end{array}$ & Manager position & $\begin{array}{l}\text { No } \\
\text { Yes }\end{array}$ & $\begin{array}{r}541 \\
29\end{array}$ & $\begin{array}{r}94.9 \\
5.1\end{array}$ \\
\hline & & $\begin{array}{ll}456 & 80.4 \\
111 & 19.6 \\
\end{array}$ & Tobacco & $\begin{array}{l}\text { No } \\
\text { Yes }\end{array}$ & $\begin{array}{l}456 \\
111\end{array}$ & $\begin{array}{l}80.4 \\
19.6\end{array}$ \\
\hline & & $\begin{array}{ll}377 & 66.6 \\
189 & 33.4\end{array}$ & Alcohol intake & $\begin{array}{l}\text { No } \\
\text { Yes }\end{array}$ & $\begin{array}{l}377 \\
189\end{array}$ & $\begin{array}{l}66.6 \\
33.4\end{array}$ \\
\hline & & $\begin{array}{ll}286 & 50.3 \\
283 & 49.7 \\
\end{array}$ & Physical activity & $\begin{array}{l}\text { No } \\
\text { Yes }\end{array}$ & $\begin{array}{l}280 \\
283\end{array}$ & $\begin{array}{l}50.3 \\
49.7\end{array}$ \\
\hline & & $\begin{array}{ll}456 & 80.4 \\
111 & 19.6\end{array}$ & Tobacco & $\begin{array}{l}\text { No } \\
\text { Yes }\end{array}$ & $\begin{array}{l}456 \\
111\end{array}$ & $\begin{array}{l}80.4 \\
19.6\end{array}$ \\
\hline & & $\begin{array}{ll}377 & 66.6 \\
189 & 33.4 \\
\end{array}$ & Alcohol intake & $\begin{array}{l}\text { No } \\
\text { Yes }\end{array}$ & $\begin{array}{l}377 \\
185 \\
\end{array}$ & $\begin{array}{l}66.6 \\
33.4 \\
\end{array}$ \\
\hline & & $\begin{array}{ll}286 & 50.3 \\
283 & 49.7 \\
\end{array}$ & Physical activity & $\begin{array}{l}\text { No } \\
\text { Yes }\end{array}$ & $\begin{array}{l}280 \\
283\end{array}$ & $\begin{array}{l}50.3 \\
49.7\end{array}$ \\
\hline & & $\begin{array}{rr}12 & 2.1 \\
146 & 25.6 \\
286 & 50.2 \\
126 & 22.1\end{array}$ & WAI & $\begin{array}{l}\text { Poor } \\
\text { Moderate } \\
\text { Good } \\
\text { Excellent }\end{array}$ & $\begin{array}{r}12 \\
146 \\
286 \\
126\end{array}$ & $\begin{array}{r}2.1 \\
25.6 \\
50.2 \\
22.1\end{array}$ \\
\hline
\end{tabular}

\section{Conclusion}

The hospital and health center coordination need to take action to improve the work ability of nursing staff, because they are civil servants, and probably will continue working at public service.

Public policies related to workplace health promotion need to be implemented in public hospital and health centre to improve the work ability of nursing staff.

\section{References}

[1] A.L.C. Kirchhof et al., Working conditions and socialdemographic characteristics related to the presence of minor psychic disorders in nursing workers. Texto \& Contexto Enf 18, (2009), 215-223.

[2] Brasil. Ministério da Saúde. VIGITEL Brasil 2008. Vigilância de fatores de risco e proteção para doenças crônicas por inquérito telefônico, 2009, Brasília. Available at: http://bvsms.saude.gov.br/bvs/publicacoes/vigitel_2008.pdf Acessed: 21March 2011.
[3] D. Camerino, P.M. Conway, B.I.J.M.V der Heijeden, M. Estryn-Behar, D. Consonni, D. Gould, H-M. Hasselhorn, Low-perceived work ability, ageing and intention to leave nursing: a comparison among 10 European countries, J. Adv. Nursing 56 (2006), 542-552.

[4] E.L. Reinhardt and F.M. Fischer, Barriers to interventions aimed at promoting the health of health care workers in Brazil, Rev. Panam. Salud Publica 25, (2009), 411-417.

[5] F.M. Fischer, F.N. Borges, L. Rotenberg, M.R. Latorre, N. Soares, P.L. Rosa, L.R. Teixeira, R. Nagai, J. Steluti, P. Landsbergis, Work ability of health care shift workers: what matters? Chronobiol Int 23, (2006), 1165-1179.

[6] J. Ilmarinen, Work ability - a comprehensive concept for occupational health research and prevention, Scand. J. Work Environn. Health 35 (2009), 1-5.

[7] K. Tuomi, J. Ilmarinen, A. Jahkola, L. Katajarinne, A. Tulkki. The Work Ability Index, Finnish Institute of Occupational Health, Helsinki, 1998.

[8] M.I. Monteiro, Socio-demographic, work, health and life style questionnaire. Work and Health Research Group, 2004, Campinas: University of Campinas.

[9] M.I. Monteiro, K. Tuomi, E.P. Goes, E.P. Hodge, H.R. Correa Filho HR, J. Ilmarinen, WAI among workers is SMEs at Wholesale, Fruits vegetables and flower market in Brazil, in: M. Kumashiro. (org.). Promotion of work ability towards productive aging. London: Taylor \& Francis, 2009, pp. 37-40.

[10] M.I. Monteiro, K. Tuomi, E.P. Goes, E.P. Hodge, H.R. Corrêa Filho, J. Ilmarinen, Work ability during life course: Brazil- 
ian workers databank analysis, in: Age management during the life course, 2011, Tampere: University of Tampere, pp. 60-67.

[11]R. Gold, S. Koskinen, J. Seitsamo, K. Tuomi, A. Polvinen, P. Sainio, Data and methods. In: R. Gould, J. Ilmarinen, J. Jär- visalo, S. Koskinen (ed), Dimensions of work ability. Results of the Health 2000 Survey, 2008, Helsinki: FIOH, KELA, ETK, KTL, pp.25-32. 